\title{
Knowledge, Attitudes, and Practices Toward Covid-19 and Associated Factors Among University Students in Mizan Tepi University, 2020
}

\author{
Abiy Tadesse Angelo \\ Daniel Shiferaw Alemayehu (ID \\ Aklilu Mamo Dacho \\ Department of Nursing, Mizan Tepi \\ University, Mizan Aman, Ethiopia
}

This article was published in the following Dove Press journal: Infection and Drug Resistance

Background: A coronavirus pandemic has reached all over the world. It is a highly contagious virus spreading from human to human by respiratory droplet infection and close contact. Applying preventive measures is very important in tackling the spread of the disease since there is no curative antiviral drug. The pandemic of the virus has impacted different institutions including the university. To overcome the impact, students are resuming face to face education by applying preventive measures of Covid-19. This study is undertaken to assess KAP in Mizan Tepi University, 2020.

Materials and Methods: A cross-sectional study was conducted among 402 randomly selected participants. A structured questionnaire was used to collect the data from December 1-10/2020. Data were entered into Epidata 3.1 and exported to SPSS version 21 for analysis. Bivariate and multivariate logistic regressions were used for analyses. A p-value of less than 0.05 was used to identify significant variables in multivariate logistic regression analysis.

Results: In this study, $47 \%, 54 \%$, and $42.8 \%$ of the students had good knowledge, positive attitude, and good practice towards Covid-19, respectively. Being from health sciences (AOR= $2.983,95 \%$ CI $(1.869,4.763))$ was significantly associated with good knowledge. Being from health sciences $(\mathrm{AOR}=1.86,95 \% \mathrm{CI}(1.169,2.970))$, female sex $(\mathrm{AOR}=0.628,95 \% \mathrm{CI}(0.405$, $0.975))$, at least one parent having diploma or degree $(\mathrm{AOR}=0.455,95 \% \mathrm{CI}(0.236,0.878))$, and $1000-1500$ ETB monthly income $(\mathrm{AOR}=0.403,95 \% \mathrm{CI}(0.189,0.856))$ were significantly associated with students' attitude. Being rural residence $(\mathrm{AOR}=1.740,95 \% \mathrm{CI}(1.136,2.663))$, positive knowledge $(\mathrm{AOR}=1.893,95 \% \mathrm{CI}(1.2322 .909))$, and positive attitude ( $\mathrm{AOR}=2.676$, $95 \%$ CI $(1.745,4.105))$ were positively associated with the students practice.

Conclusion: The KAP of the students towards the Covid-19 was low. Being a health sciences student was an explanatory variable for better knowledge. Sex, being a health science college student, parents' educational status, and monthly income were predictors of students' attitude. Residency, knowledge, and attitude were independent predictors of practice. Awareness creation on preventive behaviors among the students is highly recommended.

Keywords: Covid-19, knowledge, attitude, practice, Mizan Tepi University

\section{Introduction}

A coronavirus is a highly contagious virus causing severe acute respiratory diseases in human beings. It is caused by severe acute respiratory syndrome coronavirus 2 (SARS-CoV-2), which is a highly pathogenic virus. ${ }^{1}$ The virus has emerged in China, Wuhan state in December 2019. ${ }^{2}$ Following the report from China to the world health organization (WHO), WHO declared the diseases as a public health
Correspondence: Abiy Tadesse Angelo Email abiyutad@gmail.com 
emergency on January $300^{3}$ Since its emergence, it becomes a global concern causing 46 million mortality and 1.2 million deaths globally. ${ }^{4}$

Developing countries are also suffering from the Covid-19 pandemics. In Ethiopia, the first case of Covid19 is confirmed on 13 March 2020. After the confirmation of the first case, to mitigate the spread and to safeguard the population, Ethiopia declared a state emergency. In addition to many prohibitions, one of the actions taken by the government was banning the students from face-to-face education and discharging the university students to their home by the closing school. ${ }^{5}$ Currently, according to world meter report in-country, there were a total of 121,880 mortality and 1,897 death caused by Covid-19. ${ }^{6}$

The virus is spread by small droplets discharged from cases during coughing, sneezing, and talking. It is also transmittable by contaminating the nose and mouth with contaminated hands contaminated surfaces containing the virus. The virus has an incubation period that may range from 2 to 14 days with the main clinical manifestations of fever, cough, and shortness of breath. The virus has no curing antiviral treatment and applying the measures to reduce the transmission remains the mainstay of prevention. $^{7-9}$

Knowledge, attitude, and practices (KAP) are important in controlling the spread of the disease. Knowing the cause of the disease, signs/symptoms, and the possible methods of prevention can facilitate the proactive application of preventive measures. ${ }^{10}$

Students are now being in return to their institutions to continue the banned education with serious application of preventive measures. These groups are at risk, and the existence of a single case can cause pandemics among students. And applying essential preventive measures to reduce such risk in this group is important. But there is a shortage of findings in Ethiopia that identified the KAP among students towards Covid-19. Therefore, this study is undertaken to determine the KAP of students towards Covid-19 in Mizan Tepi University, southern Ethiopia, 2020.

\section{Materials and Methods Study Setting and Design}

The study was conducted in Mizan Tepi University. Mizan Tepi University, Mizan campus is a governmental higher institution located at $568.4 \mathrm{~km}$ from Addis Ababa in southern direction. The campus has a total of 2054 graduating students. This institutional-based quantitative cross-sectional study design was conducted from December 1-10/ 2020.

\section{Source Population}

All regular graduating class of the Mizan Tepi University, Mizan Campus.

\section{Study Participants}

Sampled graduating students during the time of data collection were the study participants.

\section{Inclusion and Exclusion Criteria}

All undergraduate students during the time of data collection were included in the study. Students who were severely ill and unwilling to participate in the study were excluded from the study.

\section{Sample Size and Sampling Technique}

The sample size was determined by using a single population proportion formula. Based on the assumption of a $95 \%$ confidence interval, $5 \%$ margin of error, the proportion of knowledge, attitude and practice towards Covid-19 among students to be $50 \%$ and $10 \%$ non-response rate; a total sample of 422 was needed.

First, 10 departments were randomly selected by the lottery method from a total of 24 departments. The proportional allocation was made to 10 departments based on their numbers to get 422 samples. Students list was obtained from their respective departments and a simple random method was used to select the study participants by lottery method.

\section{Data Collection Tool, Quality Control, and Procedure}

The questionnaire for this study purpose was developed and designed for local context after reviewing relevant studies which were used to assess the similar purpose. ${ }^{11,12}$ This structured questionnaire had four essential components related to participants' socio-demographic characteristics, knowledge-related questions, attitude related questions, and practice-related questions about Covid-19. One day orientation on data collection was given to five data collector lectures. Before actual data collection, pretesting was done on 21 students who did not participate in the study. Based on that, necessary corrections were made. Questionnaires were self-administered and all data 
collectors and supervisors strictly adhered to the WHO and Ethiopian ministry of health guidelines. Based on that, the data collectors have had gloved hand, worn mask, maintained social distancing, and used hand sanitizers between each questionnaire administration.

Thirteen items were used to assess the knowledge of students about Covid-19. The items assess the knowledge regarding the etiology, transmission route, incubation period, susceptibility, clinical manifestations, and methods of prevention. All questions have one correct answer and participants' responses were scored by giving one point to correct answers and 0 for incorrect answers including the "I don't know" response. All responses were summed up and it has a possible value of 0 to 13 . To classify the respondents as having good and poor knowledge, the mean knowledge score was computed and participants having greater or equal to mean knowledge score were considered as having good knowledge.

Similarly, seven items were used to assess the attitude of the students. The item was having rating responses and for each item, 2 points were given if the response is positive, 1 for a neutral response, and 0 for negative responses. Based on that, the participants may have a possible value from 0 to 14 . The mean attitude score was computed and participants who scored greater or equal to the mean were considered as having a positive attitude.

Practice was measured by 8 items assessing the adherence to preventive measures like wearing mask, washing hands in regular manner with soap, water and disinfectants, practice of proper methods of coughing, limiting of presence in people gathered areas, maintaining social distancing, actions to be taken if contact with confirmed case, actions to be taken if cured cases wanted to contact and actions to be taken if they develop signs and symptoms of Covid-19. Participants' response was scored by giving 1 for possible response "often or more" and 0 for "rarely or less". Similarly 1 was given for questions requiring proactive measures to be taken and 0 for responses like "I don't know what to do". The mean of practice score was computed and participants practice status is dichotomized to good practice and poor practice. In such way that individuals were considered as having a good practice if they score greater or equal to the mean practice score.

\section{Data Processing and Analysis}

Data were entered into Epidata 3.1 version after a manual check for completeness, skip patterns, and wrong coding which was corrected in the study site. The entered data were exported to SPSS version 21 for analysis. Descriptive statistics using a table of frequency distribution were used to summarize the results such as socio-demographic characteristics, knowledge, attitude, and practice. Then, the data were presented by using sentences, graphs, tables, frequencies, percentages. Both bivariate and multivariate logistic regressions were used to identify the independent predictors of knowledge, attitude, and practice. Crude odds ratio (COR) was used to identify an association between factors and dependent variable at $p<0.25$ in bivariate logistics, and to select candidate variables for multivariate logistic regression. An adjusted odds ratio (AOR) was used to describe the strength of association between the factors and dependent variables in multivariate logistics at $\mathrm{p}<0.05$.

\section{Ethical Considerations}

The study was conducted in accordance with the declaration of Helsinki, and a formal letter was obtained to conduct the study from nursing department, Mizan Tepi University. Confidentiality of the respondents was secured by excluding respondent identifiers like a name. Informed written consent was obtained from the respondents before conducting the study. All of the data collectors were strictly adhered to WHO and the ministry of health Ethiopia guidelines for Covid-19 prevention.

\section{Results \\ Socio-Demographic Characteristics of the Students}

Out of 422 participants, 402 were involved in the study and made a response rate of $95.3 \%$. The mean age of the participants was $23.1 \pm 1.7$ years with a minimum of 19 years and a maximum of 30 years old, respectively. The majority $(65.2 \%)$ of study participants were male, while $336(83.6 \%)$ were single and $232(57.7 \%)$ of the study subjects were from the rural origin. Two hundred eighty $(69.7 \%)$ of the study subjects were from none health sciences college, almost half of participants mother or father has neither degree nor diploma educational award and $362(90.0 \%)$ were none smokers (Table 1).

\section{Awareness of Students About the Covid- 19}

All of the study subjects have heard about Covid-19. Two hundred thirty $(57.2 \%)$ have gained information about Covid-19 from mass media, mainly radio or television and only $20(5 \%)$ heard information from family (Figure 1). 
Table I Socio-Demographic Characteristics of the Students in Mizan Tepi University, Southwest Ethiopia 2020, n =402

\begin{tabular}{|c|c|c|c|}
\hline \multicolumn{2}{|l|}{ Characteristics } & \multirow{3}{*}{$\begin{array}{l}\text { Frequency } \\
262 \\
140\end{array}$} & \multirow{3}{*}{$\begin{array}{l}\text { Percentage } \\
65.2 \\
34.8\end{array}$} \\
\hline Gender & Male & & \\
\hline & Female & & \\
\hline \multirow[t]{4}{*}{ Marital status } & Single & 336 & 83.6 \\
\hline & Married & 37 & 9.2 \\
\hline & Widowed & 3 & 0.7 \\
\hline & Divorced & 26 & 6.5 \\
\hline \multirow[t]{2}{*}{ Students residence } & Urban & 170 & 42.3 \\
\hline & Rural & 232 & 57.7 \\
\hline \multirow[t]{3}{*}{ Parents completed diploma or higher education } & None & 207 & 51.5 \\
\hline & One of them & 132 & 32.8 \\
\hline & Both of them & 63 & 15.7 \\
\hline \multirow[t]{4}{*}{ Religion } & Orthodox & 293 & 72.9 \\
\hline & Protestant & 50 & 12.4 \\
\hline & Muslim & 56 & 13.9 \\
\hline & Wakfeta & 3 & 0.7 \\
\hline \multirow[t]{3}{*}{ Monthly income in ETB } & $<1000$ & 249 & 61.9 \\
\hline & $1000-1500$ & 108 & 26.9 \\
\hline & $\geq 1500$ & 45 & 11.2 \\
\hline \multirow[t]{2}{*}{ College of students } & Health sciences & 122 & 30.3 \\
\hline & None health sciences & 280 & 69.7 \\
\hline \multirow[t]{2}{*}{ Smoking } & Yes & 40 & 10.0 \\
\hline & No & 362 & 90.0 \\
\hline
\end{tabular}

Knowledge of Students Toward Covid-19 Three hundred fifteen (78.4\%) of the students mentioned the causes of Covid-19 as a virus, $306(76.1 \%)$ stated respiratory droplet and close contact as the method of transmission, the majority $(58.2 \%)$ identified the correct incubation period and only $153(38.1 \%)$ knew that generally, people are susceptible for Covid-19.

Two hundred fifty-seven (63.9\%) of the study subjects mentioned fever and dry cough as the main clinical manifestation of the Covid-19, 171 (42.5\%) considered that all persons infected with Covid-19 show clinical manifestation, while $244(60.7 \%)$ responded that application of nonpharmacological methods are important for prevention and, and majority (74.4\%) knew that wearing face masks can reduce transmission.

One hundred seventy-three $(43.0 \%)$ considered that eating garlic or onions cannot prevent the disease, 162 (40.3\%) answered that taking antibiotics is optimal treatment for Covid-19, 205 (51.0\%) responded that there is curing or protective vaccine and effective treatment of Covid-19, while 154 (38.3\%) considered that global mortality rate from Covid-19 is below 5\% and majority (71.4\%) knew that Covid-19 can be transmitted by contaminating the eye, nose, or mouth from contaminated surfaces by Covid-19 (Table 2). One hundred eighty-nine $(47.0 \%)$ of the study subjects had scored the knowledge score above than the mean knowledge score (7.1) and had good knowledge about Covid-19 (Figure 2).

\section{Attitude of the Students Towards Covid- 19}

About half of the students agreed that they are worried for might getting Covid-19, 182 (45.3\%) agree for preventive measures should be only applied by risk groups and older adults. Two hundred sixty eight (66.7\%) agree for visiting the health facility when they develop symptoms, 275 $(68.4 \%)$ agreed that limit of movement by individuals decreases the disease transmission, and 158 (39.3\%) agreed that students living in the campus are vulnerable for Covid-19. Two hundred five (51.0\%) agreed that the outbreak has impacted their study, and 184 (45.8\%) had agreed that eating raw vegetables and wild animals do not 


\section{Source of information about Covid-19 for students}

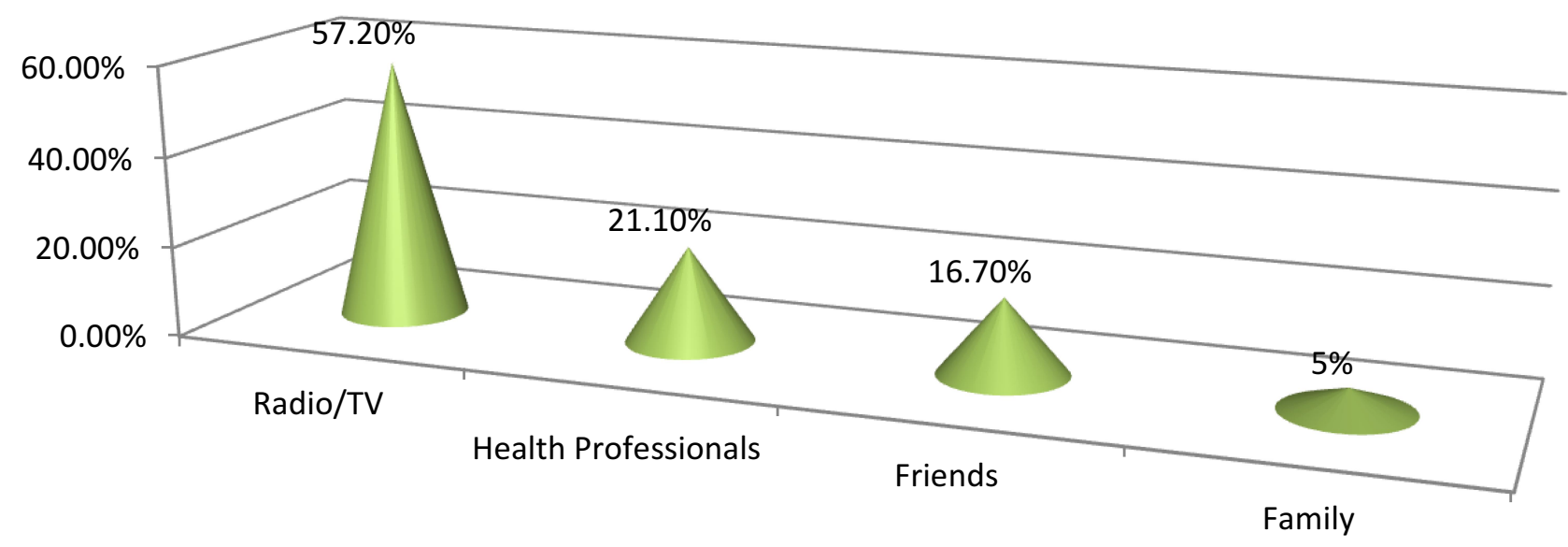

Figure I Source of information about Covid-19 to students in Mizan Tepi University, southwest Ethiopia, $2020, \mathrm{n}=402$.

impact the transmission (Table 3). Overall 217 (54.0\%) of the study participants had scored attitude score greater than the mean attitude score (7.4) and had a positive attitude towards Covid-19 prevention (Figure 3).

\section{Practice of the Students in Covid-19 Prevention}

Two hundred fifty-eight (64.2\%) of the students committed to washing hands regularly, $224(55.7 \%)$ practiced proper method of coughing, while $221(55.0 \%)$ did not wear face mask, and $246(61.4 \%)$ did not gather in areas where the mass of people presented. The majority $(60.6 \%)$ did not maintain social distancing, $209(52.0 \%)$ of the study subjects did not take proactive measure when contacting the active Covid-19 case, while 265 (65.9\%) avoided meeting with cured Covid-19 patients and 206 (51.2\%) answered to take proactive measures when developing signs and symptoms of Covid-19 (Table 4). Overall 230 (57.2\%) of the respondents scored practice below the mean practice score (4.18) and were having a poor practice of Covid-19 prevention (Figure 4).

\section{Factors Associated with Knowledge, Attitude and Practice Towards Covid-19 Among Students}

In bivariate analysis sex, being from health science, college or not, income status and parents educational status were significantly associated with students' knowledge at $\mathrm{p}<0.25$. Likewise, sex, college of the students, income, smoking, and parents' educational status were significantly associated with students' attitudes in a bivariate analysis at $\mathrm{p}<0.25$. Smoking habit, the attitude of the students, knowledge, and residence were significantly associated with the practice towards Covid-19 prevention in a bivariate analysis at $\mathrm{p}<0.25$ (Table 5).

Multivariate logistic regression analysis revealed that the odds of knowing about Covid-19 health sciences college students were almost 3 times more compared to those none health sciences students $(\mathrm{AOR}=2.983,95 \% \mathrm{CI}$ $(1.869,4.763))$. Except for the students learning college, none of the other variables are associated with knowledge in this study during multiple logistics regression analysis.

In this study, the odds of having a positive attitude towards Covid-19 prevention among health sciences students were almost 2 times more than none health sciences students $(\mathrm{AOR}=1.86,95 \% \mathrm{CI}(1.169,2.970))$. Students having at least one parent who had a diploma or degree were almost $55 \%$ times less likely to have a positive attitude about Covid-19 prevention than students having both parents with diploma or degree education $(\mathrm{AOR}=$ $0.455,95 \%$ CI $(0.236,0.878))$. Students having monthly income between 1000 and 1500 Ethiopian Birr were almost $60 \%$ times less likely to have positive attitude about Covid-19 prevention than students having more than 1500 Ethiopian Birr as monthly income (AOR= $0.403,95 \%$ CI $(0.189,0.856))$. Similarly, the odds of having a positive attitude towards Covid-19 among female 
Table 2 Participants' Knowledge About Covid-19 in Mizan Tepi University, Southwest Ethiopia, 2020, n = 402

\begin{tabular}{|c|c|c|c|}
\hline Variables & Category & Frequency & Percentage \\
\hline \multirow[t]{3}{*}{ What type of infectious is Covid-19? } & Bacterial & 18 & 4.5 \\
\hline & Viral & 315 & 78.4 \\
\hline & I do not know & 69 & 17.2 \\
\hline \multirow[t]{4}{*}{ The main transmission method } & Respiratory droplet and close contact & 306 & 76.1 \\
\hline & Water & 24 & 6.0 \\
\hline & Food & 29 & 7.2 \\
\hline & I do not know & 43 & 10.7 \\
\hline \multirow[t]{4}{*}{ Incubation period of Covid-19 } & I-14 days & 234 & 58.2 \\
\hline & 5-9 days & 36 & 9.0 \\
\hline & More than 14 days & 106 & 26.4 \\
\hline & I do not know & 26 & 6.5 \\
\hline \multirow[t]{5}{*}{ Who is susceptible for Covid-19? } & The old & 113 & 28.1 \\
\hline & People are generally susceptible & 153 & 38.1 \\
\hline & Young adults & 11 & 2.7 \\
\hline & People with pre-existing disease & 94 & 23.4 \\
\hline & I do not know & 31 & 7.7 \\
\hline \multirow[t]{6}{*}{ Main clinical manifestations of Covid-19 } & Fever and dry cough & 257 & 63.9 \\
\hline & Fatigue & 38 & 9.5 \\
\hline & Stuffy and runny nose & 42 & 10.4 \\
\hline & Back pain & 8 & 2.0 \\
\hline & Diarrhea & 12 & 3.0 \\
\hline & I do not know & 45 & 11.2 \\
\hline \multirow[t]{3}{*}{ All infected individuals with Covid-19 develop sign and symptoms. } & Yes & 171 & 42.5 \\
\hline & No & 165 & 41.0 \\
\hline & I do not know & 66 & 16.4 \\
\hline \multirow[t]{3}{*}{ None pharmacological method of prevention is important for Covid-19. } & Yes & 244 & 60.7 \\
\hline & No & 89 & 22.1 \\
\hline & I do not know & 69 & 17.2 \\
\hline \multirow[t]{3}{*}{ Wearing mask can prevent transmission } & Yes & 299 & 74.4 \\
\hline & No & 69 & 17.2 \\
\hline & I do not know & 34 & 8.5 \\
\hline \multirow[t]{3}{*}{ Eating garlic and onions can prevent transmission. } & Yes & 156 & 38.8 \\
\hline & No & 173 & 43.0 \\
\hline & I do not know & 73 & 18.2 \\
\hline \multirow[t]{3}{*}{ Taking anti-biotic is optimal method of Covid-19 treatment and prevention. } & Yes & 162 & 40.3 \\
\hline & No & 167 & 41.5 \\
\hline & I do not know & 73 & 18.2 \\
\hline \multirow[t]{3}{*}{ There is effective curing and protecting vaccine and treatment modalities for Covid-19. } & Yes & 205 & 51.0 \\
\hline & No & 127 & 31.6 \\
\hline & I do not know & 70 & 17.4 \\
\hline \multirow[t]{3}{*}{ Globally mortality rate from Covid-19 is below $5 \%$. } & Yes & 154 & 38.3 \\
\hline & No & 148 & 36.8 \\
\hline & I do not know & 100 & 24.9 \\
\hline \multirow[t]{3}{*}{ Does Covid-19 transmitted with contact of contaminated surfaces? } & Yes & 287 & 71.4 \\
\hline & No & 53 & 13.2 \\
\hline & I do not know & 62 & 15.4 \\
\hline
\end{tabular}




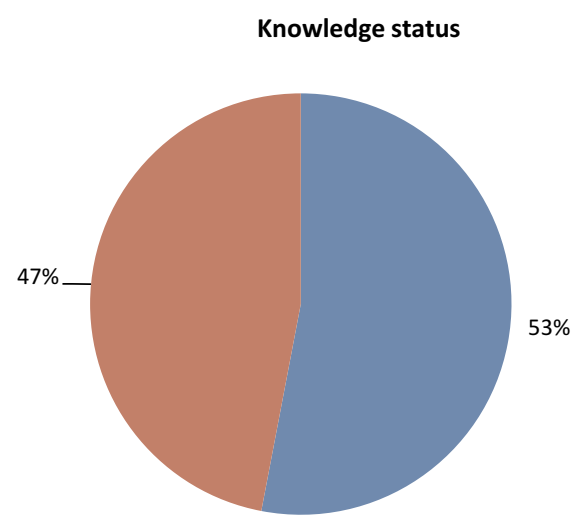

Figure 2 Knowledge status of the students to Covid-19 in Mizan Tepi University, southwest Ethiopia, 2020, n=402.

students were $37 \%$ times less likely compared to male students $(\mathrm{AOR}=0.628,95 \% \mathrm{CI}(0.405,0.975))$.

Multiple logistics regression analysis showed that students who had positive attitude were almost 3 times more likely to have a good practice of Covid-19 prevention than students having negative attitudes $(\mathrm{AOR}=2.676,95 \mathrm{CI}$ $(1.745,4.105))$. Students who had good knowledge were almost 2 times more likely to have a good practice of Covid-19 prevention than students having poor knowledge
$(\mathrm{AOR}=1.893,95 \mathrm{CI}(1.232,2.909))$. Also the odds of having a good practice in Covid-19 prevention among students who stayed in rural areas were almost 2 times more likely compared to those stayed in urban area $(\mathrm{AOR}=1.740,95 \% \mathrm{CI}(1.136,2.663))($ Table 5$)$.

\section{Discussion}

The study aimed to assess knowledge, attitude, and practice of the students towards Covid-19 in Mizan Tepi University. In this study, all of the students had heard about the Covid-19, with the majority (57.2\%) gained information from mass media mainly radio and television. This finding was in line with studies done in India, where $99.6 \%$ of the study participants were heard about the Covid-19. ${ }^{12}$

The study revealed that $78.4 \%$ of the study participants replied about the cause of Covid-19 was a virus. This finding is much lower than the study of China, in which $97.3 \%$ stated the cause as a virus. ${ }^{11}$ The possible reason for this variation may be due to the variation of sample size where larger sample size was used in the china study. Another possible reason may be due to variation of enabling factors of awareness about the exact cause of

Table 3 Attitude of the Students Towards Covid-19, in Mizan Tepi University, Southwest Ethiopia, 2020, n=402

\begin{tabular}{|c|c|c|c|}
\hline Variables & Categories & Frequency & Percentage \\
\hline Are you worried that you might get Covid-19? & $\begin{array}{l}\text { Agree } \\
\text { Do not agree } \\
\text { Neutral }\end{array}$ & $\begin{array}{l}202 \\
136 \\
64\end{array}$ & $\begin{array}{l}50.2 \\
33.8 \\
15.9\end{array}$ \\
\hline $\begin{array}{l}\text { Do you think that Covid-19 prevention measures should only be applied by older adults and age } \\
\text { groups most risk? }\end{array}$ & $\begin{array}{l}\text { Agree } \\
\text { Do not agree } \\
\text { Neutral }\end{array}$ & $\begin{array}{l}182 \\
170 \\
50\end{array}$ & $\begin{array}{l}45.3 \\
42.3 \\
12.4\end{array}$ \\
\hline In the event that i develop symptoms of Covid-19, I will seek to visit health facility. & $\begin{array}{l}\text { Agree } \\
\text { Do not agree } \\
\text { Neutral }\end{array}$ & $\begin{array}{l}268 \\
98 \\
36\end{array}$ & $\begin{array}{l}66.7 \\
24.4 \\
9.0\end{array}$ \\
\hline Do you think that limit of the movement decreases the transmission? & $\begin{array}{l}\text { Agree } \\
\text { Do not agree } \\
\text { Neutral }\end{array}$ & $\begin{array}{l}275 \\
97 \\
30\end{array}$ & $\begin{array}{l}68.4 \\
24.1 \\
7.5\end{array}$ \\
\hline Do you think that students in campus are invincible for Covid-19? & $\begin{array}{l}\text { Agree } \\
\text { Do not agree } \\
\text { Neutral }\end{array}$ & $\begin{array}{l}158 \\
132 \\
112\end{array}$ & $\begin{array}{l}39.3 \\
32.8 \\
27.9\end{array}$ \\
\hline Do you think that outbreak has impacted your study? & $\begin{array}{l}\text { Agree } \\
\text { Do not agree } \\
\text { Neutral }\end{array}$ & $\begin{array}{l}205 \\
133 \\
64\end{array}$ & $\begin{array}{l}51.0 \\
33.1 \\
15.9\end{array}$ \\
\hline $\begin{array}{l}\text { Do you think that consumptions of raw vegetables and wild animal products have no role in } \\
\text { transmissions of Covid-19? }\end{array}$ & $\begin{array}{l}\text { Agree } \\
\text { Do not agree } \\
\text { Neutral }\end{array}$ & $\begin{array}{l}184 \\
153 \\
65\end{array}$ & $\begin{array}{l}45.8 \\
38.1 \\
16.2\end{array}$ \\
\hline
\end{tabular}




\section{Attitude Status}

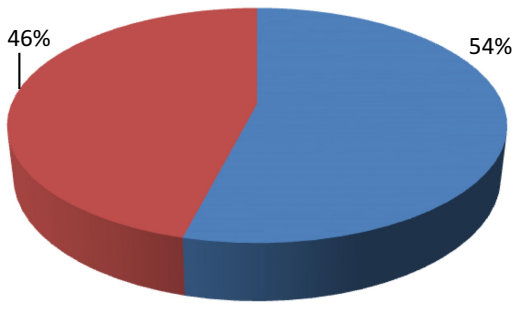

- Positive attitude

Negative attitude

Figure 3 Students' attitude status to Covid-19 in Mizan Tepi University, southwest Ethiopia, 2020, $n=402$.

the disease which may be influenced by the socio-economic and educational status. This is in fact that socioeconomic status can impact awareness. ${ }^{13,14}$ The finding is however much better than a study from Indonesia, which depicted that only $39 \%$ knew that virus causes the disease. $^{15}$

The study depicted that $76.1 \%$ have known the correct mode of transmission. This finding is almost in line with studies from Indonesia (78.99\%) and Palestine (78.5\%) of the undergraduate students knew the correct mode of the transmission. ${ }^{15,16}$ This finding is better than a study from India in which $68 \%$ knew the correct methods of transmission. ${ }^{12}$ However, this finding from the current study is much lower than a study from china that $98.9 \%$ knew the correct methods of transmission. The study also showed that more than half $(58.2 \%)$ of the students knew the correct incubation period of the disease. This finding is much lower than study from Palestine $(95.8 \%)^{16}$ and lowers than study from China (66.4\%). ${ }^{11}$ The possible suggestions for such variations may be due to variations of sample characteristics, in which the numbers of students from health sciences related field involved in the study from Palestine and China are more than this study.

The study also pointed out that $63.9 \%$ of students knew the correct sign and symptoms of the disease by stating fever and dry cough. This finding is lower than studies from Indonesia (89.71\%), ${ }^{15}$ China $(98.6 \%),{ }^{11}$ and India $(86.7 \%) .{ }^{17}$ The possible reason for the variations may be due to difference in sample size in comparing with Indonesia and China studies. But the variations compared with Indian study is that, only medical students were involved in India, while both medical and none medical involved in that of the current study. Knowing the sign and symptoms of the Covid-19 is very important for early quarantine to prevent the possible spread among the student community.

The study showed that $(47.0 \%)$ of the students had good knowledge about the Covid-19. This finding is better

Table 4 Students' Practice Towards Covid-19 Prevention in Mizan Tepi University, Southwest Ethiopia, 2020 , n=402

\begin{tabular}{|c|c|c|c|}
\hline Variables & Categories & Frequency & Percentage \\
\hline \multirow{2}{*}{ Were you committed to hand wash? } & Often or more & 258 & 64.2 \\
\hline & Rarely or less & 144 & 35.8 \\
\hline \multirow{2}{*}{$\begin{array}{l}\text { Did you practice the proper methods of coughing and } \\
\text { sneezing etiquette? }\end{array}$} & Often or more & 224 & 55.7 \\
\hline & Rarely or less & 178 & 44.3 \\
\hline \multirow[t]{2}{*}{ Did you wear face mask regularly? } & Often or more & 181 & 45.0 \\
\hline & Rarely or less & 221 & 55.0 \\
\hline \multirow{2}{*}{$\begin{array}{l}\text { Were you in areas of many people gathered like in bar } \\
\text { and restaurants? }\end{array}$} & Often or more & 155 & 38.6 \\
\hline & Rarely or less & 247 & 61.4 \\
\hline \multirow{2}{*}{$\begin{array}{l}\text { Did you maintain safe distance between you and } \\
\text { individual? }\end{array}$} & Often or more & 158 & 39.3 \\
\hline & Rarely or less & 244 & 60.6 \\
\hline \multirow[t]{2}{*}{$\begin{array}{l}\text { What would you do if you had close contact with } \\
\text { confirmed case? }\end{array}$} & $\begin{array}{l}\text { Pro-actively report to the institution and I isolate my } \\
\text { self }\end{array}$ & 193 & 48.0 \\
\hline & I do not know what to do & 209 & 52.0 \\
\hline \multirow{2}{*}{$\begin{array}{l}\text { What would you do if someone cured from Covid-19 } \\
\text { wants to meet you? }\end{array}$} & I will meet and show kind ness & 137 & 34.1 \\
\hline & I will excuse him and avoid contact & 265 & 65.9 \\
\hline \multirow[t]{2}{*}{ What would you do if you had fever and dry cough? } & $\begin{array}{l}\text { I will analyze the situation rationally and report to } \\
\text { nearby health facility }\end{array}$ & 206 & 51.2 \\
\hline & I do not know what to do & 196 & 48.8 \\
\hline
\end{tabular}




\section{Practice status}

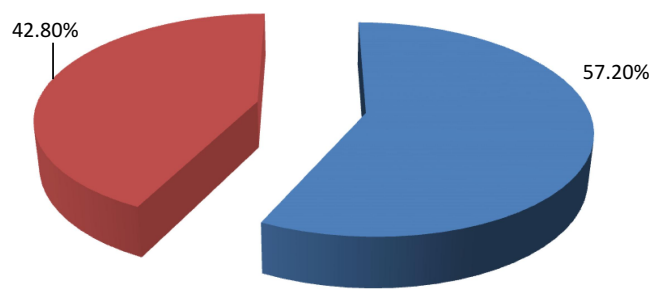

- Poor practice Good Practice

Figure 4 Practice status among students toward Covid- 19 in Mizan Tepi University, southwest Ethiopia, 2020, n=402.

than studies done in Beret $(41.4 \%)^{16}$ and India (40\%). ${ }^{12}$ This difference could be due to difference in methods of categorizations to good and poor knowledge, in which the late Indian study used arbitrary cutoff $70 \%$ and that of the current study used the mean knowledge score as the cutoff value to dichotomize poor and good knowledge. However, the finding is much lower than a study from China (82.3\%). ${ }^{11}$ Having knowledge about a given disease very important in applying appropriate effective preventive measures. ${ }^{17}$ When doing this, the spread of the disease can be easily tackled, but in this study the knowledge level of the students is low. In the present study college of the students is only the factor associated with the students' level of knowledge and the odds of knowing about Covid19 among health sciences college students was almost 3 times more compared to those none health sciences students $(\mathrm{AOR}=2.983,95 \% \mathrm{CI}(1.869,4.763))$. This finding is supported by a study from China, ${ }^{11}$ in which the odds of good knowledge in medical students were more significant than none of the medical students. This is because medical students can get information about the disease from their education.

The study revealed that $50.2 \%$ of students agreed that they are worried about being infected by the virus. This finding is inconsistent with the study from China. ${ }^{11}$ The possible reason for such variation may be due to the gap in awareness of effective self-protective measures. This can influence the students' preventive behavior in preventing the disease. Two hundred seventy five (68.4\%) of the study subjects agreed that the limit of the movement decreases the transmission. This is lower than the study done in India $(100 \%) .{ }^{12}$ Overall, $54 \%$ of the students have a positive attitude. This finding is lower than the study done in China (73.81\%). ${ }^{11}$ In this study, student's attitude about the Covid-19 was predicted by variables like being from health science college $(\mathrm{AOR}=1.86,95 \%$ CI $(1.169$, $2.970)$ ), parent having at least diploma or degree $(\mathrm{AOR}=$ $0.455,95 \%$ CI $(0.236,0.878))$, monthly income between 1000 and $1500 \mathrm{ETB}(\mathrm{AOR}=0.403,95 \% \mathrm{CI}(0.189,0.856))$ and being female sex (AOR $=0.628,95 \%$ CI $(0.405$, $0.975)$ ). This finding is supported by a study from Japan, where male sex is positively associated with attitude. ${ }^{18}$ But it is opposed by a study from China. ${ }^{11}$ None of the studies opposes or supports the rest of the predictors.

In the present study, $64.2 \%$ washed hands in a regular manner. This is inconsistent with a study from India in which all of the students adhered to regular hand washing. ${ }^{12}$ Regular hand washing is one of the effective WHO recommendations for tackling the virus spread. The study also identified that only $45 \%$ practiced regular wearing of the face mask. This finding is much lower than the Indian study $(91 \%){ }^{19}$

Overall, only $42.8 \%$ had good practice about Covid-19 prevention methods and taken proactive measures. This is not in line with a study from China (87.9\%). ${ }^{11}$ The possible suggestion for such variation may be due to the difference in tools used to assess the practice of the students. In this study, factors identified for the poor practice were knowledge, attitude, and residence. In the present study, good knowledge is positively associated with practicing Covid-19 prevention ( $\mathrm{AOR}=1.893,95 \mathrm{CI}(1.232,2.909))$. This finding is supported by a study from China ${ }^{11}$ in which students with higher grades showed to practice more. A positive attitude is positively associated with the prevention of Covid-19 in this study $(\mathrm{AOR}=2.676,95 \mathrm{CI}(1.745,4.105))$. Also being a rural residency is positively associated with the practice $(\mathrm{AOR}=1.740,95 \% \mathrm{CI}(1.136,2.663))$. This contradicting with a study from Japan, where the odd of practices among students from the capital area are more likely than the counterpart. ${ }^{18}$ This finding from the current study is suggesting that dissemination of information about Covid-19 has not brought the difference in implementation of prevention, as it is expected that living in rural is easy to access information about prevention than those living in rural.

\section{Conclusion}

The knowledge, attitude, and practice towards Covid-19 among students were found to be low. The odds of good knowledge about Covid-19 among non-health science students were low. Factors associated with students' attitudes about Covid-19 were parents' educational status, sex, students learning college, and monthly income. Good knowledge, positive attitude, and rural residency were positively associated with 


\begin{tabular}{|c|c|c|c|c|c|c|c|c|c|c|c|c|c|}
\hline & & 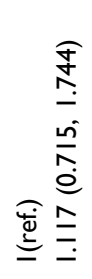 & 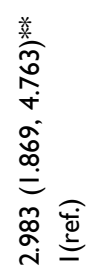 & 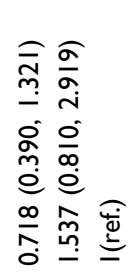 & 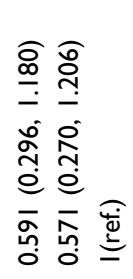 & & 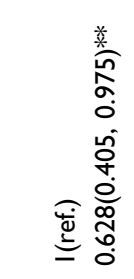 & 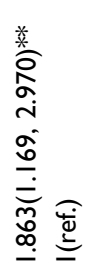 & 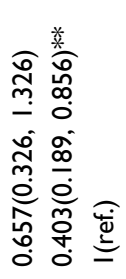 & 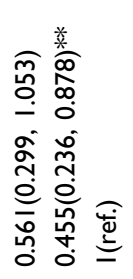 & & 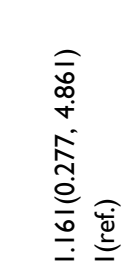 & 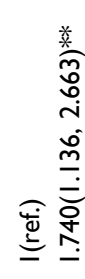 \\
\hline & & 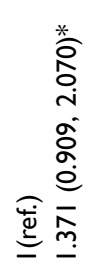 & 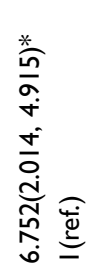 & 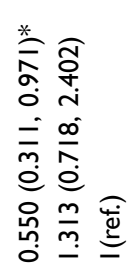 & 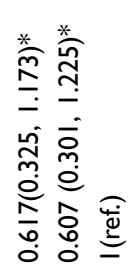 & & 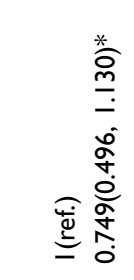 & 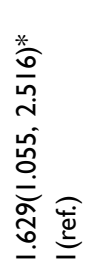 & 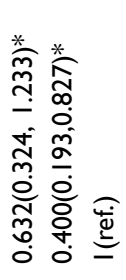 & 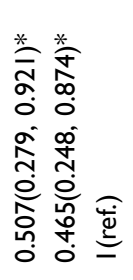 & & 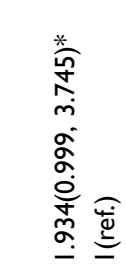 & 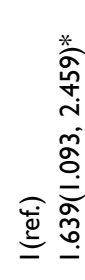 \\
\hline & 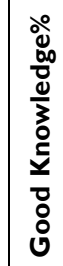 & 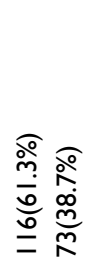 & 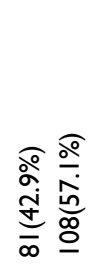 & 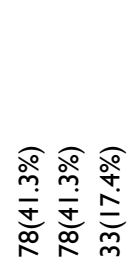 & 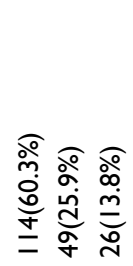 & & 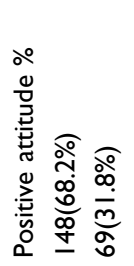 & 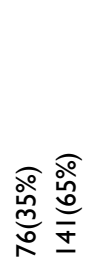 & 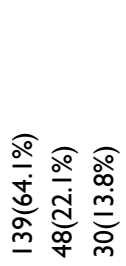 & 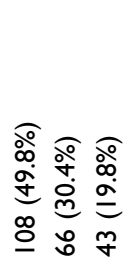 & & 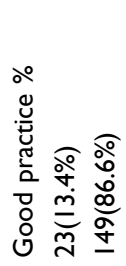 & 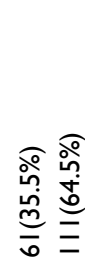 \\
\hline & 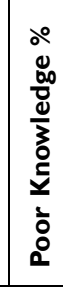 & 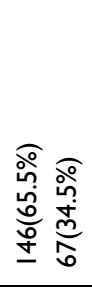 & 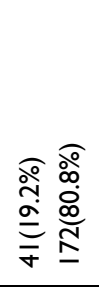 & 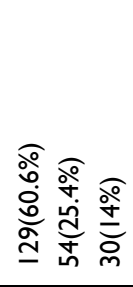 & 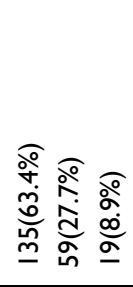 & & 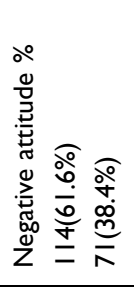 & 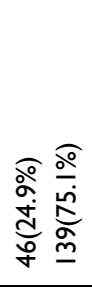 & 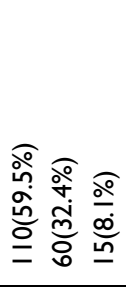 & 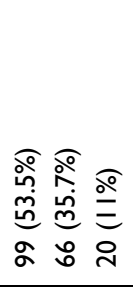 & & 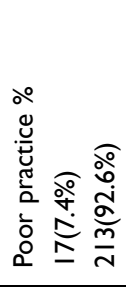 & 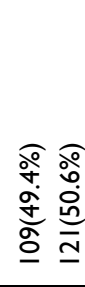 \\
\hline & & 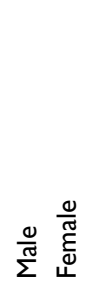 & 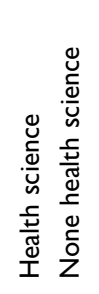 & 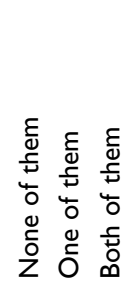 & 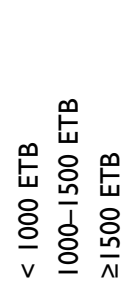 & & 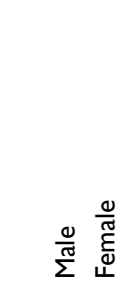 & 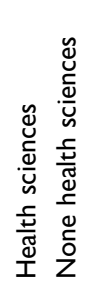 & 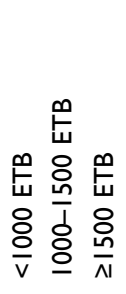 & 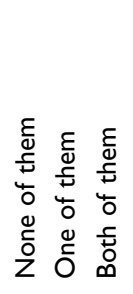 & & $\stackrel{y}{x}$ z & 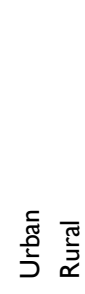 \\
\hline & & હે & $\frac{\stackrel{80}{0}}{\frac{ \pm 0}{0}}$ & 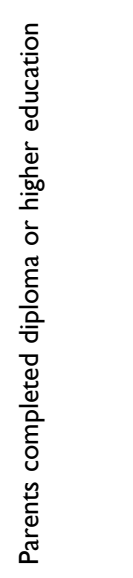 & $\begin{array}{l}\stackrel{0}{\tilde{\varepsilon}} \\
\underline{\underline{G}}\end{array}$ & 总 & ڤ & $\begin{array}{l}\stackrel{0}{\circ} \\
\stackrel{\stackrel{0}{0}}{0}\end{array}$ & $\begin{array}{l}\stackrel{0}{\tilde{\sigma}} \\
\underline{\underline{G}}\end{array}$ & 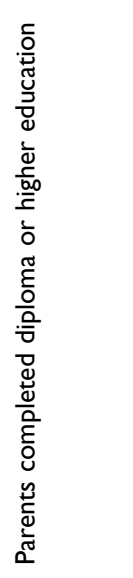 & 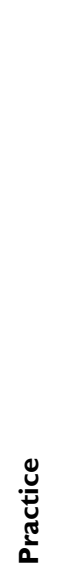 & 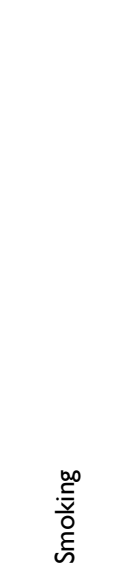 & 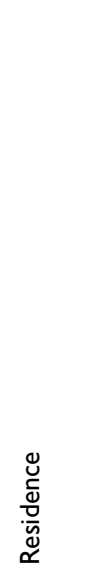 \\
\hline
\end{tabular}


having a good practice in Covid-19 prevention among the students. Awareness creation for preventive behaviors among students is highly recommended.

\section{Data Sharing Statement}

Not applicable.

\section{Consent for Publication}

Not applicable.

\section{Acknowledgments}

We are very grateful to all study participants for their commitment in responding to questionnaires and all data collectors for their collaboration up to the end of the study.

\section{Author Contributions}

All authors made a significant contribution to the work reported, whether that is in the conception, study design, execution, acquisition of data, analysis, and interpretation, or in all these areas; took part in drafting, revising, or critically reviewing the article; gave final approval of the version to be published; have agreed on the journal to which the article has been submitted; and agree to be accountable for all aspects of the work.

\section{Funding}

No fund was received.

\section{Disclosure}

The authors declare that they have no conflicts of interest for this work.

\section{References}

1. World health organization. Coronavirus disease 2019 (covid-19) Papua New Guinea situation report 6. Available from: Https://www.who.int/ docs/default-source/wpro $\% 2 \mathrm{~d} \% 2 \mathrm{~d}$-documents/countries/papua-newguinea/covid-19/png-covid-19-health-situation-report-06.pdf.

2. Zhu N, Zhang DY, Wang WL, Li XW, Yang B, Song JD. A novel coronavirus from patients with pneumonia in china. $N$ Engl $J$ Med. 2020;382(8):727-733. doi:10.1056/NEJMoa2001017

3. World health organization. 2019-nCoV outbreak is an emergency of international concern; 2020. Available from: http://www.euro.who.int/en/healthtopics/health-emergencies/international-health-regulations/news/news/2020/ 2/2019-ncov-outbreak-is-an-emergency-of-international-concern.

4. World health organization. Covid-19 weekly epidemiological update. 2020

5. Federal negarit gazette. 2020

6. Ethiopia coronavirus. 2020

7. Chen N, Zhou M, Dong X, et al. Epidemiological and clinical characteristics of 99 cases of 2019 novel coronavirus pneumonia in wuhan, china: a descriptive study. Lancet. 2020;395(10223):507-513. doi:10.1016/s0140-6736(20)30211-7 
8. CDC. How to protect yourself \& others; 2019. Available from: https://www.cdc.gov/coronavirus/2019-ncov/prevent-getting-sick/pre vention.html.

9. Bi Q, Wu Y, Mei S, et al. Epidemiology and transmission of covid-19 in 391 cases and 1286 of their close contacts in shenzhen, china: a retrospective cohort study. Lancet Infect Dis. 2020;20(8):911-919. doi:10.1016/s1473-3099(20)30287-5

10. Szymona-Pałkowska K, Janowski K, Pedrycz A. Knowledge of the disease, perceived social support, and cognitive appraisals in women with urinary incontinence. Biomed Res Int. 2016;2016:3694792. [Pmid:28097132]. doi:10.1155/2016/3694792

11. Peng Y, Pei C, Zheng Y. A cross-sectional survey of knowledge, attitude and practice associated with covid-19 among undergraduate students in china. BMC Public Health. 2020;20(1):1292. doi:10.1186/ s12889-020-09392-z

12. Jagajeet S, Anshuman S, Dutt S. Assessing the knowledge, attitude and practices of students regarding the covid-19 pandemic. J Health Manag. 2020;2(22).

13. Palardy GJ. Differential school effects among low, middle and high social class composition schools: a multi-group, multilevel latent growth curve analysis. Sch Eff Sch Improv. 2008;19(1):21-49. doi:10.1080/09243450801936845
14. Perry LB, Mcconney A. Does the ses of the school matter? An examination of socioeconomic status and student achievement using pisa 2003. Teach Coll Rec. 2010;112:1137-1162.

15. Saefi M, Fauzi A, Kristiana E, et al. Survey data of covid-19-related knowledge, attitude, and practices among indonesian undergraduate students. Data Brief. 2020;31:105855. doi:10.1016/j.dib.2020.105855

16. Hani A, Ni'meh A, Lilian S, et al. Knowledge, attitudes and practices about coronavirus disease (covid-19) among Birzeit University students: a cross-sectional study. 2020. doi:10.21203/rs.3.rs-83268/v1

17. Hauck K. The economics of infectious diseases. Oxford University Press. 2018:1-34. Available from. http://economics.oxfordre.com/ view/10.1093/acrefore/9780190625979.001.0001/acrefore9780190625979-e-251.

18. Hatabu A, Mao X, Zhou Y, et al. knowledge, attitudes, and practices toward covid-19 among university students in japan and associated factors: an online cross-sectional survey. PLoS One. 2020;15(12): e0244350. doi:10.1371/journal.pone.0244350

19. Sonam M, Puneet G, Richa S, Pravesh R. Knowledge, attitude, and practice towards coronavirus disease 2019 (covid-19) among medical students: a cross-sectional study. Acute Dis. 2020;9(3):100-104. doi:10.4103/2221-6189.283886

\section{Publish your work in this journal}

Infection and Drug Resistance is an international, peer-reviewed openaccess journal that focuses on the optimal treatment of infection (bacterial, fungal and viral) and the development and institution of preventive strategies to minimize the development and spread of resistance. The journal is specifically concerned with the epidemiology of antibiotic resistance and the mechanisms of resistance development and diffusion in both hospitals and the community. The manuscript management system is completely online and includes a very quick and fair peerreview system, which is all easy to use. Visit http://www.dovepress.com/ testimonials.php to read real quotes from published authors. 